\title{
The Migration from AM Radio to FM Radio in Brazil: Implications for Listeners and Local Broadcasters
}

\author{
Nair Prata ${ }^{1 *}$ \\ (iD) 0000-0002-9127-7720 \\ Rafael Medeiros ${ }^{2 * *}$ \\ (iD) 0000-0002-0327-3982 \\ ${ }^{1}$ Universidade Federal de Ouro Preto, BRAZIL \\ 2 Universidade Federal de Santa Maria, BRAZIL \\ *Corresponding author: nairprata@uol.com.br \\ ** Corresponding author: rfmedeiros13@gmail.com
}

Citation: Prata, N., \& Medeiros, R. (2021). The Migration from AM Radio to FM Radio in Brazil: Implications for Listeners and Local Broadcasters. Online Journal of Communication and Media Technologies, 11(3), e202110. https://doi.org/10.30935/ojcmt/11081

\section{ARTICLE INFO}

Received: 30 Oct 2020

Accepted: 7 Jun 2021

\begin{abstract}
The migration of AM (Amplitude Modulation) to FM (Frequency Modulation) radios is the most important change in the configuration of Brazilian broadcasting in years, reaching more than $90 \%$ of the stations in the country. This process started in 2013 and the local radio stations were the first ones affected. In Brazil, local radio is an important part of the daily life of small cities, in listening habits shared between people of several generations. This article is based on a wideranging survey conducted with listeners from Itatiaia Ouro Preto Radio, a local broadcaster in the Brazilian state of Minas Gerais. The methodology combined documentary research, application of questionnaires and interviews with the aim of exploring in depth the listeners' speeches about the intersections between the migration of the station, the changes in radio listening experiences and the potential of local radio in the small historic city. The results show that the changes caused by the migration of AM stations are challenging for these radio stations and are felt by a loyal audience, used to the traditional characteristics of these stations. The phenomenon impacts the forms of production, consumption, circulation, proximity dynamics and key radio functions.
\end{abstract}

Keywords: Brazil, local radio, AM radio migration, reception research, audience

\section{INTRODUCTION}

During its history, radio has undergone several changes based on technological development, legislation determinations or the perception of transformation of the public. In reference to the constant process of media transformation, Fidler (1997) uses the term mediamorphosis to think of these phenomena as the adaptation of the communication system to changes in the media ecosystem, considering that new media arise from metamorphosis, transformations, from old media that continue to evolve and adapt to changes.

Based on this concept, Prata (2009) developed the term radiomorphosis to affirm that radio seeks this adaptation and that the medium on the internet, although configured with Hertzian characteristics, "at the same time inserts new formats, while reconfiguring old elements, in a mixture that transforms the vehicle into a great constellation of sound, textual and imagetic signs" (Prata, 2009, p. 80) ${ }^{1}$. Lopez agrees that "the context of radiomorphosis affects practices, management, forms of transmission, diffusion and enjoyment and the very definition of radio format and content" (Lopez, 2017, p. 1). The radio is a changing medium.

\footnotetext{
${ }^{1}$ All quotes from the Portuguese or Spanish language used in this text were freely translated.
} 
In 2013, the Federal Government started the process of migrating AM to FM stations in Brazil, a major metamorphosis that has reconfigured different spheres of broadcasting in the country. The phenomenon has subjected migrant radio stations to a new conformation, changing their forms of production, the possibilities of broadcasting and consuming their content and even the configuration of the audience. As a recent process and of great magnitude - affecting more than $90 \%$ of Brazilian AM radio stations, the consequences and effects of this metamorphosis are gradually being known, through research that addresses different biases of the phenomenon. The local radio stations were the first ones affected by the migration, since in smaller cities there were channels already available for transmitting the signal from the stations that would start to operate in FM.

The questions about local radio in Brazil demand some careful reflections because they trigger different characteristics inherent to social construction, proximity dynamics, geographic landmarks, cultural formation, interaction dynamics and, more recently, to mediations by digital means. Local media focus on the social life of the community, reverberating values, traditions, meanings and transmitting important information in the daily lives of the population.

This article unfolds from a reception study carried out with listeners from Itatiaia Ouro Preto Radio, a local broadcaster in the city of Ouro Preto, Minas Gerais, in Brazil. The research aimed to identify possible changes in the experiences of listening and producing meanings from the migration process of the station to FM (Medeiros, 2019). Based on a multi-methodological basis that combined the application of questionnaires, interviews with listeners and radio managers and textual discursive analysis, the study was developed considering the challenges of migration to the local broadcaster and the perception of listeners. It was possible to verify the structure of the social location of radio listening, thinking that the listeners are inserted in variegated social nuclei that effectively influence their memories and perceptions of everyday reality.

As it is an emerging phenomenon and has different implications, the article is structured to initially introduce the general overview of the migration process of AM radios in Brazil, then explain the theoretical framework and discussions on local broadcasting and, finally, explore the results of research in two instances: broadcasters and listeners, verifying questions regarding the social function of local radio for inland communities.

\section{UNDERSTANDING THE MIGRATION FROM AM RADIO TO FM RADIO IN BRAZIL}

Based on the studies by García Avilés and other authors (2008), Ferraretto and Kischinhevsky (2010) reflect on four basic areas of broadcasting that are being modified by new technologies and the inclusion of the media in the convergence environment: technological; business; professional and content. These are factors that involve the basic infrastructure for the operation of a radio up to business models and programming formats. In 2013, the Brazilian government confirmed the migration process from AM to FM stations, a new major change that comprises the fields described by the authors and has transformed broadcasting in the country in a comprehensive way.

The changes in the structure of AM radio stations represent an old request from broadcasters based on the fall in profit of these radios after a long period of devaluation due to the lack of interest from the Government, the technological changes that benefited only Modulated Frequency and the competition by advertisers, who was expanded by digital networks and the introduction of new devices. Investments in the digital TV system further aggravated these claims by radio owners, while this digitalization of TV stations represented a possibility for the intended change in the Brazilian radio broadcasting system.

The main reasons cited by the then Ministry of Communications for migration are linked to improved sound quality, less signal interference and the possibility of tuning through mobile devices such as smartphones - which only support the FM band. In addition, economic factors can also be pointed out as a motivation for the beginning of this process, because AM broadcasters have been suffering with the drop in audience and advertisers and the channels released by these radios may be used by telephone companies. It should be made clear that most of the data available on audience variations on the radio comes from surveys conducted in metropolitan regions, which may not represent the reality of the inlands of Brazil. In this way, the government uses general data to justify the motivations for the start of the migration process and disregards the various peculiarities of local radio and audiences. 


\section{THE MIGRATION OF AM RADIO IN BRAZIL}

\section{TOTAL RADIO STATIONS IN BRAZIL}
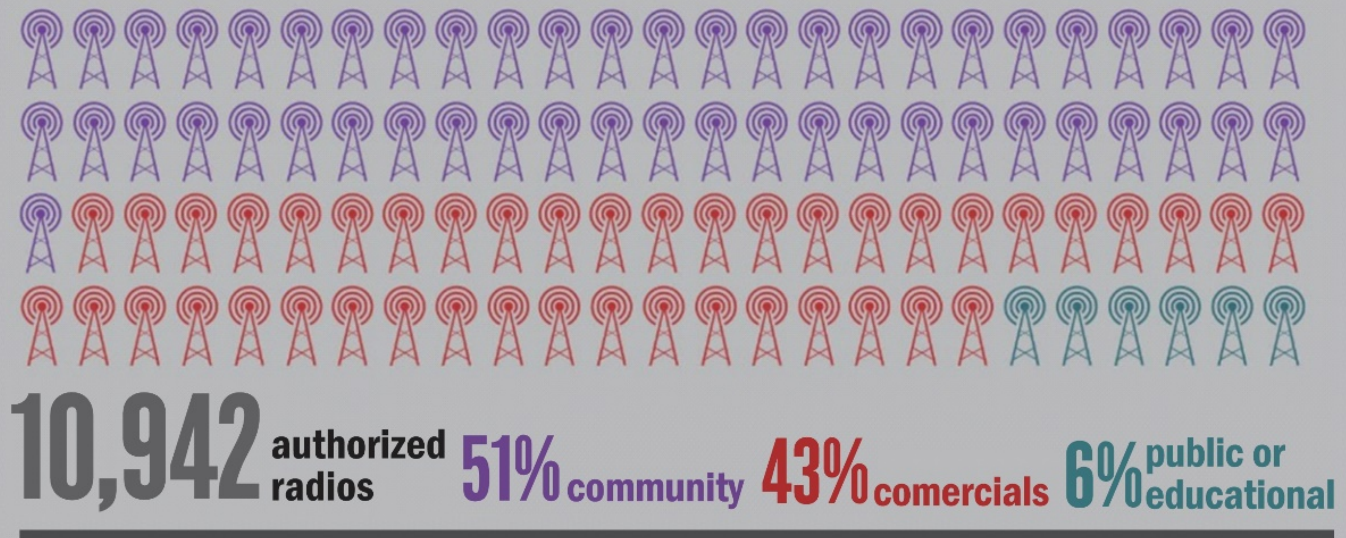

\section{NUMBERS OF THE MIGRATION}

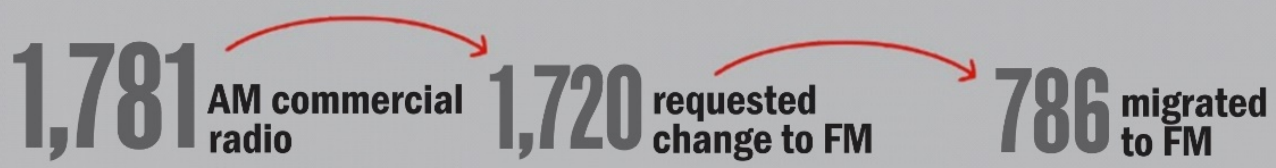

Figure 1. Extent of the AM radio migration process in Brazil

After studies carried out since 2010, the process was made official by the then president Dilma Rousseff on November 7, 2013. During the official ceremony of the beginning of the migration, the then president of the Brazilian Association of Radio and Television Broadcasters (ABERT), Daniel Slaviero, highlighted that "the signing of the decree is the most relevant fact for AM radio in the last 50 years" (Slaviero in Macedo, 2013). The stagnation of Brazilian broadcasting, especially of AM broadcasters, is in fact notorious also because it is a system based on outdated legislation that disregards several technological developments already assimilated by a considerable number of listeners and even by many communication companies such as, for example, mobile radio consumption.

As an example of this behavior of radio consumption, Del Bianco and Prata (2018) clarify that "the cell phone has become the main gateway for radio consumption, in addition to extending the forms of mobility previously restricted to transistorized and automobile devices" (Del Bianco \& Prata, 2018, p. 99). By making available on the market only cell phones and automotive sounds that are exclusively compatible with tuning in FM radio, the industry has accelerated the weakening of AM stations and thus contributed to the acceptability of the migration process. Although many AM radio stations, including local ones, also transmit via streaming over the Internet, it is necessary to take into account, once again, the low quality of the connection and the still limited range of services. The consumption of radio in mobility also allowed to increase the interactive potentials of this medium, to complex narratives using spaces now multimedia. In this way, mobile radio consumption is not just about the possibility of listening by cell phone, but represents a change in the structure of sound broadcasting, in listening experiences and modes of audio consumption transformations that did not include traditional AM broadcasters.

In this context, in 2020, of the 1,781 commercial broadcasters operating on the AM frequency in Brazil, 1,720 requested a change in frequency and 786 of them are already operating in the FM band ${ }^{2}$. Figure 1 shows the extent of the AM radio migration process in Brazil.

${ }^{2}$ Data from the Brazilian Association of Radio and Television Broadcasters (ABERT) updated in February 2020. 
With more than $75 \%$ of the requesting broadcasters already authorized to operate in Modulated Frequency, the Federal Government has set for 2022 the conclusion of all migration activities. According to the Ministry of Science, Technology and Innovations, national and regional AM radio stations that have refused to join the migration process continue to operate normally, but there are studies that claim that the current AM model will not be sustainable for many years. In practice, non-migrant AM broadcasters will cease to exist or will be even more isolated in the universe of national broadcasting. In the next topic, questions about local radio configurations in Brazil will be addressed to highlight the implications of migration on these stations.

\section{DYNAMICS OF BRAZILIAN LOCAL RADIO}

When approaching radio in the local context, the investigation flexes different dynamics that converge to the communicational field, seeking to some extent the daily representations that build the characteristics of the sociability of the place linked to "interchangeable ways of thinking, to ethos, meaning values contained in things, words, gestures, behaviors and ideas" (Pesavento, 2006, p. 36). All these spheres have repercussions on the forms of local media, engendered in the routine of the city and inseparable from everyday social relations. Local Brazilian broadcasters are able to reinforce social and cultural ties and identities because the radio "is centered on the social, economic, political and cultural life of its area of coverage and also on everything that happens outside and that has repercussions on the life of the community" (Cebrián Herreros, 2001, p. 98).

The dynamics of proximity on local radio are sewn together by these social and identity components. In this sense, Peruzzo (2005, p. 78) highlights that "the media of proximity is characterized by bonds of belonging, rooted in the experience and reflected in a commitment to the place and to quality information". When the media recognizes the local singularities and associates its language with the daily specificities of the population, it creates bonds that go beyond the dialogic transmitter-listener association. The physical insertion of the station in the middle of its audience can facilitate the listener's interest, the interactive possibilities and increase the feeling of belonging. This association of the feeling of belonging with the circumscribed and singularized territory is apprehended by the French sociologist Alain Bourdin (2001), when reflecting that "every group of belonging is in principle associated with a territory" (p. 35) and even though "all spatiality it expresses belonging to a we, which builds and manifests itself through territorial cuts".

When the collective imagination conceives the importance of the media, the existence of a nearby broadcaster generates this feeling of belonging because it reverberates events in the listener's daily life, who see themselves represented and perceive on the radio another component of insertion in city's life. Through the radio he can send messages, ask for music, interact with announcers, he can listen to himself on this station - which also happens to be his. As evidenced by Raddatz (2011, p. 1), the local radio, especially the traditional AM, "fulfills its function focused mainly on information and service, but strengthens its trajectory by affinity with the listener who sees it and is represented in it". In small cities of Brazil, radio is important in the dynamics of daily life, announcing lost objects, broadcasting death notes, invitations to religious celebrations, and even serving as a communication link between people from the municipality's headquarters and rural inhabitants through messages that a citizen assigns to another. In this sense, Soares, quoted by Bertolotto (2018), explains that "AM enters through igarapés ${ }^{3}$ to the riverside communities. In the flour houses, the sound is of the radio. It strengthens our identity and brings knowledge. In the Amazon, it is as essential as WhatsApp for the people of the city "“ (Soares as cited in Bertolotto, 2018, para. 3).

In the context of the development of the migration process, some of the characteristics of the radio in relation to the audience should be changed. Taking the example of the municipality of Ouro Preto, where the empirical research was carried out, all twelve rural districts of the city will be without coverage by Itatiaia Ouro Preto Radio after the AM signal is turned off. This represents an impact with regard to local identity because the media helps to conform or modify modes of identity, since "cultural media consumption participates in

\footnotetext{
${ }^{3}$ In Brazil, igarapés are water courses that have little depth and run through the interior of the forests. The inhabitants of these areas use the igarapés as modes of transport and communication.

${ }^{4}$ Many people who live in areas of the Brazilian Amazon do not have access to a cellular or internet signal, which is why AM radio is so important for these populations.
} 
the organization of daily life and the conformation of cultural competence" (Ronsini, 2007, p. 70). The concept of local identity takes on an important role in the dialogical convergence between the radio station and the listener, in the production and maintenance of discourses and meanings about a common space.

In this way, "cultural identities are points of identification, unstable points of identification or suture, made within the discourses of culture and history" (Hall, 2006, p. 70). It is in this sense that the idea of local identity is appropriate in this paper, since the definition of place is crossed by the question of identity, considering that the place says of "a restricted, well-defined space, within which the life of a group or group of people. It has a precise outline, to the point of becoming a territorial guide for daily habits" (Ortiz, 1999, p. 54).

Thus, "the local shapes the world of daily life, being itself the founder of the relationship with the individual's world, but also of the relationship with the other, of the common construction of the meaning that makes the social bond" (Bourdin, 2001, p. 36). Communication appears in these interlocutions between everyday life, maintaining identity and the possibility of representation in the sense that Martín-Barbero gives it: "Communication is perceived as the daily scenario of social recognition, of the constitution and expression of the imaginary from which people represent what they fear or have the right to expect, their fears and their hopes" (Martín-Barbero, 2003, p. 63).

For the local population, the media, especially the radio, play an important role in the constitution of subjectivities, dialogisms and social relations. As Kischinhevsky evidences, "radio is the most local means of electronic communication ever developed, even though it today has a planetary reach" (Kischinhevsky, 2016, p. 134) $)^{5}$. Furthermore, the social function of the radio and its relevant position in various aspects of daily life in small towns are linked to the perceptions noted above by Martín-Berbero. Also, in this perspective, an important social function of local communication is to highlight issues that have no space in the mainstream media, favoring social mobilization around problems that directly affect people's lives and are often neglected by government officials. Peruzzo (2005) concludes that, in the local media, "the main role is in the citizens, who, through non-profit civil society organizations, establish communication processes with a view to social mobilization and the expansion of citizenship" (Peruzzo, 2005, p. 43). Thus, local radio is placed as a mediator between the demands of the population and governmental bodies.

One of the important social functions of communication is to provide public utility services, reporting on events that directly affect people's lives. The consequences of migration in small stations have a direct impact on the character of local radio. Itatiaia Ouro Preto Radio is the main means of communication used by the city hall of the heritage city ${ }^{6}$ to provide the population with information on vaccination campaigns, garbage collection, medical care and other extremely relevant to the community, especially for rural areas.

\section{METHODOLOGY}

The methodological path is divided into two fronts: broadcaster and listeners. In the initial phases of the research, a documentary search found the existence of little data that could contextualize the constitution of Itatiaia Ouro Preto Radio. Thus, after locating subjects who directly contributed to the conception and effectiveness of the station, oral history interviews were conducted in order to identify the founding characteristics of the station.

The use of this method for the historical recovery of the broadcaster is justified by its usefulness in "obtaining data about the past that did not exist in files and documents of another nature, such as writings, iconographic and audiovisuals" (Ribeiro, 2015, p. 75). The interviews were conducted with the station's first journalist and programmer, Maurílio Torres; with the first secretary, Maria Nazaré Oliveira and with the bishop emeritus Francisco Barroso Filho (Dom Barroso), supporter of the radio in the first years of the station.

\footnotetext{
${ }^{5}$ For the author, the form of relationship established between the audience and the medium means that the radio has to "listen to its audiences permanently". These audiences have the possibility to point out to the broadcaster what they want to hear, they can contribute information, broadcast news and interact more closely with communicators, "forcing the radio to be better, to provide public utility services, to inform correctly and ethically, to present social and cultural diversity, without representing clichés and stereotypes" (Kischinhevsky, 2016, p. 134).

${ }^{6}$ Ouro Preto was recognized as a World Heritage Site by UNESCO on September 5, 1980, being the first cultural property in Brazil listed for its historical and architectural value.
} 
Table 1. Identification of interviewed listeners

\begin{tabular}{llcc}
\hline Name & Gender & Age & Occupation \\
\hline Ana Luisa Reis & Female & 27 & Journalist \\
Conceição Aparecida da Mata & Female & 53 & Teacher \\
Euclides José Gomes & Male & 52 & Bricklayer \\
Geraldo Antônio Gomes & Male & 53 & Bricklayer \\
Maria Aparecida Albergaria & Female & 78 & Seamstress \\
Fátima da Silva Paiva & Female & 46 & Public agent \\
Vicentina Rosa de Oliveira & Female & 52 & Seamstress \\
\hline
\end{tabular}

To understand the specific issues related to the migration process at the broadcaster, a questionnaire and data from the collective research of the Radio and Sound Media Research Group of the Brazilian Society for Interdisciplinary Communication Studies (Intercom) on the impact of the migration process of AM radio for FM (Prata \& Del Bianco, 2018) were used. The listener's perspective, central to the research, is understood through the application of online questionnaires and interviews for a voluntary sample. The data are explored based on the methods of Textual Discursive Analysis.

For an initial understanding of the behavior of Itatiaia Ouro Preto Radio's audience regarding their listening experiences, use of devices, perceptions about the radio station and about the migration process, an online questionnaire was made available for four months to be completed. Of the 47 respondents to the questionnaire, eighteen were interested in being interviewed initially, however, after the contacts, seven interviews were effectively carried out in order to deepen the data obtained, substantiate the information and detail specific questions. Table 1 shows some initial data from the interviewed listeners.

The questions defined for the interviews started from the observation of the questionnaire data, but were not limited to them. In agreement with Moraes and Galiazzi, the "qualitative research intends to come to interpret the phenomena that it investigates from a rigorous and judicious analysis" of the existing texts or of the analysis material produced from observations and interviews (Moraes \& Galiazzi, 2016, p. 33). The qualitative basis of the research thus takes the interviews as central elements of the investigation, but it does not disregard any other unit of meaning previously generated in this multimethodological matrix thought for the research. The results of the investigation are presented in the final topics of this text, first under the bias of the broadcaster, then looking at the listener.

\section{RESULTS}

\section{Challenges of Migration to a Local Broadcaster: The Case of Itatiaia Ouro Preto Radio}

In 1974, the main and most enduring media in the city of Ouro Preto emerged: Itatiaia Ouro Preto Radio. Markedly, the radio was constituted with the characteristics of a local broadcaster, reverberating events of the daily life of the Ouro Preto population, inserting itself in the daily life of the city and confirming a place of affection among the inhabitants. According to one of the first employees of the station, Maria Nazare de Oliveira (personal communication, August, 2018), the pioneering programming of the radio was configured based on local news and Brazilian popular music, seeking from the beginning to insert itself in the daily life of the city and get closer to the population. In addition, the broadcaster has always released personal messages from residents, especially among the population of the urban area and the rural areas and districts of these cities, since Ouro Preto Radio was sometimes the fastest way of communication between the most distant locations. This function is still quite common in many broadcasters in rural areas, especially those that broadcast in Modulated Amplitude. These general characteristics of traditional AM radio stations are being modified with the migration process.

Itatiaia Ouro Preto Radio signed the addendum of grant, the first phase of the migration, in March 2017 and started to operate in FM in July of the same year, but the station's promotional director, Daniel Pedrosa, says in an interview with the authors that "the process started well before, just when the government announced the possibility of migration" (D. Pedrosa, personal communication, July, 2018). The beginning of this process took place with technical planning, since the presentation of a technical report is one of the requirements for migrant broadcasters, and financial, since the radio changed several pieces of equipment. 
Also, according to Daniel Pedrosa, investments were made "in better computers for the studio, the technical center was set up, with audio blades, Wheatstone table, audio processors and servers" (D. Pedrosa, personal communication, July, 2018). In the questionnaire answered for the collective research of the Radio and Sound Media Research Group of Intercom, the broadcaster claims to have invested an amount between nine hundred thousand and one million reais to carry out the migration, including expenses with adapting the grant, purchase and installation of equipment, infrastructure and investment in programming and professionals. Only with the adaptation of the grant, Itatiaia Ouro Preto Radio paid R $\$ 94,717.67$ (US \$16,786). The director states that financial planning was necessary to enable adaptation.

Like Ouro Preto radio, $60 \%$ of broadcasters considered the cost paid to the government high or very high, since the expenses go beyond the amounts paid for adapting the grant, but include "purchase and installation of equipment, infrastructure and investment in programming and professionals" (Prata \& Del Bianco, 2018, p. 51). Bearing in mind that the first migrant broadcasters are located in small or medium-sized cities and that AM radio stations were going through financial crises, it is justifiable that the value is considered high. According to Prata and Del Bianco (2018), several alternatives were necessary for some radio stations to be able to cover expenses with the migration process, including the sale of goods and bank loans. Even so, the expectation for an increase in the audience and, consequently, with the financial gain, makes managers in general consider the amounts paid to be an investment.

Since the beginning of the migration process, Itatiaia Ouro Preto Radio has been concerned with the reach that the broadcaster would have after turning off the AM signal, having postponed the completion of the steps precisely to review some technical processes, such as the location of the transmission tower, and serve the municipality of Ouro Preto in its entirety. This concern starts from the configuration of the Ouro Preto's relief that is "quite rugged, with steep slopes and deep valleys [...]. The territorial limits of the Ouro Preto headquarters district are comprised in a valley surrounded by the mountains of Ouro Preto, to the north, and Itacolomi, to the south" (Calil, 2018, p. 22). The configuration of the relief has already made the studies for allocation of the station's new transmission tower to be revised. This was the main reason why Itatiaia Ouro Preto Radio still broadcast the same AM channel on FM.

Simultaneous broadcast ${ }^{7}$ has been an alternative chosen by many migrant broadcasters for the transition period, considering that "broadcasting from a new frequency is synonymous with the renewal of programming and the broadcasters consulted feel challenged to produce and present new content" (Prata \& Del Bianco, 2018, p. 59). In addition, there is still the perception that listeners are already used to programming, to announcers, to the formats of programs and news, to the musical genres broadcast and to other aspects that define AM stations as traditional.

The reduction of the coverage area is a general concern regarding the migration process, since it can generate zones of silence and leave rural communities without coverage from their local broadcasters. Daniel Pedrosa is emphatic in stating that the radio is concerned with serving not only the municipality's headquarters, but also the rural districts:

We are working to have a better reach and not fail to serve the districts, our main concern is with the city of Ouro Preto (headquarters and rural districts), to always carry information. But, it may not work in some locations in some districts because our region is so mountainous and the frequency is modulated [...]. We are very concerned, and very careful to serve the entire region, which is why we are working to promote the change of our FM transmission tower (D. Pedrosa, personal communication, July, 2018).

It should be noted that the coverage area after completing the migration is still being studied by technicians from the Itatiaia Company. During the migration process, the project was reformulated to relocate the antenna, as the Ouro Preto relief would cause barriers in the signal and considerably reduce the range. The signal from Itatiaia Ouro Preto Radio would reach 18.6 miles in a straight line if there was no interference from the relief, but currently the FM signal works only at the headquarters of the municipality. As much as

\footnotetext{
${ }^{7}$ Transmission of the same content on AM and FM channels.
} 
they are not left behind by national and regional news, the population of rural areas will lose a source of relevant information regarding their daily activities.

\section{Migration in the Perception of Listeners}

The change to FM has been gradually introduced into the listening routine of the Itatiaia Ouro Preto Radio listeners, and the broadcaster has publicized the possibility of tuning in to FM through local newspapers, in advertising actions in the streets of Ouro Preto and in programming itself. The dissemination actions have had an effect, since $93.6 \%$ of the people who answered the questionnaire claim to know that Itatiaia Ouro Preto Radio can be heard on Modulated Frequency, however the adherence to FM was small, considering that only $19.1 \%$ of the listeners replied that they already listen to the radio through the new frequency. The listeners who were interviewed reflect the data obtained by the questionnaire in the same way. All of them learned through the station itself that it is possible to tune the radio to FM, but most of them only listen in AM or do not care about the type of tuning, just like Maria Aparecida, since the programming is the same. "I knew there was going to be FM on the radio, but I hear them both. There are days that on AM and there are days that on FM (M. A. Albergaria, personal communication, December, 2018).

Local radio stations prioritize journalistic programs aimed at providing services and sports. News about health, politics, education, sanitation and city traffic conditions is common on local AM stations. Fátima says that listeners are already used to the programming and the format of the programs and that is why these factors should not be changed after the migration. She cites the example of her mother-in-law as a person already used to the content of the station: "My mother-in-law was listening to the morning show to hear people's complaints. She knew she was going to have that. She lived there in Mariana ${ }^{8}$, near the garden, so there was no water, she called the radio and waited until she heard her complaint" (F. Paiva, personal communication, January, 2019). Ana Luisa agrees that "on this specific radio, it is good to keep the program because there are many elderly people who listen and wait for it to be that same" (A. L. Reis, personal communication, January, 2019). Geraldo adds: "If you make a change, the listener will have to get used to enjoying the other program. If you move until I get discouraged from listening to Itatiaia" (G. Gomes, personal communication, January, 2019).

The interviewees who listen to more than one Ouro Preto radio were able to indicate some characteristics of Itatiaia Ouro Preto Radio, the only AM station in the city, which differ from other local stations - these are working on FM. Among the characteristics pointed out are: type of voiceover, program format, music, signal range, quantity and types of information conveyed and the permanence of the same programs and speakers over the years at Itatiaia Ouro Preto Radio. Fátima indicates different characteristics between Itatiaia Ouro Preto Radio (AM) and Real Radio (FM): "Real's songs are better, newer" (F. Paiva, personal communication, January, 2019), for Ana Luisa, "Real is more entertainment. Itatiaia's programming is older" (A. L. Reis, personal communication, January, 2019). Geraldo realizes that "Itatiaia has more information on everything, politics, sports, social" (G. Gomes, personal communication, January, 2019).

In this transition period from AM to FM, the audience of broadcasters tends to be dispersed and the forms of interaction multiple. The migrant radio stations will have to know how to break the distances and relate to the listener who does not have a cell phone and to the listener who would only contact him by WhatsApp. Analyzing the interviews with listeners from Itatiaia Ouro Preto Radio for the research, this statement is clear. Maria Aparecida does not use a cell phone, but interacts with the broadcaster through a telephone call; Fátima, even having access to online social networks and WhatsApp, still prefers to call to ask for music or make a complaint. Geraldo only interacted with the radio over the phone, but he hardly gets in contact with the broadcaster. Therefore, we agree with Kischinhevsky (2016) in the understanding that it is not possible to extol a horizontal character of communication even with the arrival of online social networks or other platforms that facilitated interaction considering that the social conditions of listeners are not homogeneous.

Even though they understand the core of the migration process, listeners do not have more information about the phenomenon, which it can cause in their daily listening to the radio or about the progress of the phenomenon at Itatiaia Ouro Preto Radio. "They say that this change was to improve. Improved the sound. The sound improved. I hear both. [...] AM occasionally tilt, it gets bad, but you can hear it" (M. A. Albergaria,

\footnotetext{
${ }^{8}$ City near Ouro Preto.
} 
personal communication, December, 2018). Ana Luisa also understands that migration has as main objective the improvement of the signal, even though she considers that the AM frequency is not bad. Euclides and Conceição listen through both frequencies and stated that they did not notice any difference in the sound quality. Geraldo understands, in a certain way, that with the tuning only in FM the radio will lose coverage: "You leave here, you arrive in Cachoeira ${ }^{9}$ you no longer hear Ouro Preto Radio well, the territory of Ouro Preto is large, you go there in Antônio Pereira is no longer arriving. [...] Ouro Preto Radio AM is one thing, FM is another thing" (G. Gomes, personal communication, January, 2019). Of course, these are the few changes that can be noticed, since the broadcaster has not yet turned off the AM signal and has not made any changes to the programming. Even though they know that the sound quality is better, most of the listeners who answered the questionnaire intend to continue listening to the AM radio until the signal is turned off.

The migration process is still unknown to both listeners and Itatiaia Ouro Preto Radio. As it is an unprecedented process in Brazil and with emerging results, any forecast may be flawed. To the detriment of this, from what was exposed in this topic, it is possible to verify that, after the migration process is completed, the changes foreseen by Itatiaia Ouro Preto Radio will be felt by this faithful public and accustomed to the characteristics of the broadcaster.

\section{CONCLUSIONS}

The migration process from AM radio to FM radio in Brazil should not be understood as homogeneous, but rather understood as a complex and vast phenomenon, with varied impacts for broadcasters and listeners from different social contexts. For many locations, AM radio continues to be the main means of communication for its ability to faithfully reflect the daily life of the city or even because only it manages to reach more distant places, as is the case in the rural areas of Ouro Preto.

One of the biggest problems with the migration of AM to FM stations is precisely the decrease in the signal from the stations and the worsening of zones of silence. Itatiaia Ouro Preto Radio, the focus of the investigation that originated this article, will reach eight times less after the migration to FM, failing to reach the twelve rural districts of Ouro Preto. For the residents of these places, the move of the city's most traditional radio to FM may represent the end of these dynamics, impacting on the feeling of belonging to the city itself, since the local broadcasters also serve to maintain traditions and demarcate identities.

This fact is repeated in other broadcasters and, as exposed in this text, mainly affects populations from small localities and with lower development rates, in addition to populations from remote communities. In a country with severe areas of deserts of news and zones of silence, the decrease in the scope of its most popular and democratic media may represent an aggravation of misinformation and misperception about reality.

With characteristics markedly of AM radio, Itatiaia Ouro Preto Radio maintains the same programming and speakers for many years, with occasional changes, but preserving the programming bases in local news and sports. With strong aspects of traditionality, seriousness and quality, the radio has won the confidence of a population that is averse to any changes in the station.

In this sense, the migration to FM puts to the test the ability to reinvent radio as the most democratic means of communication in the country, and, specifically, the Ouro Preto station while rooted in the city and with characteristics already assimilated by listeners. As a new process, in all instances there is a difficulty in anticipating its aspects, especially those related to the listener's reactions. Even so, it is known that the process has an impact on the social functions of local radio, as a medium inserted in the daily life of small Brazilian cities, and in the listening dynamics, sewn by memorial ties, the use of devices and the feeling of proximity to the traditional radio stations.

Author contributions: All authors were involved in concept, design, collection of data, interpretation, writing, and critically revising the article. All authors approve final version of the article.

Funding: The authors received no financial support for the research and/or authorship of this article.

Declaration of interest: Authors declare no competing interest.

Data availability: Data generated or analysed during this study are available from the authors on request.

${ }^{9}$ Ouro Preto rural area. 


\section{REFERENCES}

Bertolotto, R. (2018). País sem sintonia: depois de integrar o Brasil por décadas, o rádio vive mudanças que podem provocar o efeito contrário [Country out of tune: after being part of Brazil for decades, radio is experiencing changes that could have the opposite effect]. UOL Tab. https://tab.uol.com.br

Bourdin, A. (2001). A questão local [the local issue]. DP\&A.

Calil, M. R. (2018). Expansão urbana em Ouro Preto-MG: o risco de ocupar encostas mineradas [Urban expansion in Ouro Preto-MG: The risk of occupying mined slopes]. Federal University of Viçosa. Viçosa, Minas Gerais, Brazil.

Cebrián Herreros, M. (2001). La radio en la convergência multimedia [The radio in the multimedia convergence]. Gedisa.

Del Bianco, N. R., \& Prata, N. (2018). Rádio, mobilidade e ubiquidade: análise do projeto de inclusão mobile digital da Abert [Radio, mobility and ubiquity: analysis of Abert's mobile digital inclusion project]. Intercom, Revista Brasileira de Ciências da Comunicação, 41(1). São Paulo Jan./Apr. 2018. https://doi.org/10.1590/1809-5844201815

Ferraretto, L. A., \& Kischinhevsky, M. (2010). Rádio e convergência: uma abordagem pela economia política da comunicação [Radio and convergence: an approach to the political economy of communication]. Revista Famecos, 17(3). https://doi.org/10.15448/1980-3729.2010.3.8185

Fidler, R. (1997). Mediamorphosis - Understanding New Media. Pine Forge Press.

Hall, S. (2006). A identidade cultural na pós-modernidade [Cultural identity in postmodernity]. DP\&A.

Kischinhevsky, M. (2016). Rádio e mídias sociais: Mediações e interações radiofônicas em plataformas digitais de comunicação [Radio and social media: Mediations and radio interactions in digital communication platforms]. Mauad X.

Lopez, D. C. (2017). La radio en narratives immersives: le contenu journalistique et l'audience [Radio in immersive narratives: journalistic content and audience]. (D. C. Lopez, Trans.). In S. Paulain (Ed.), La radio du futur: du téléchromophotophonotétroscope aux postradiomorphoses, Cahiers d'histoire de la radiodiffusion, 132.

Macedo, D. (2013). Dilma assina decreto autorizando migração de rádios AM para FM [Dilma signs a decree authorizing the migration from AM to FM radios]. EBC. https://bit.ly/3ec3eMx

Martín-Barbero, J. (2003). Globalização comunicacional e transformação cultural [Communication globalization and cultural transformation]. In D. Moraes (Ed.), Por uma outra comunicação: mídia, mundialização cultural e poder. Record.

Medeiros, R. (2019). O rádio e a cidade patrimônio: experiências de escuta, localismo e migração nos discursos de ouvintes Ouro-Pretanos [The radio and the heritage city: listening experiences, localism and migration in the speeches of Ouro-Pretanos listeners] (Masters dissertation), Institute of Applied Social Sciences, Universidade Federal de Ouro Preto, Mariana.

Moraes, R., \& Galiazzi, M. (2016). Análise Textual Discursiva [Discursive Textual Analysis]. Editora Unijuí.

Ortiz, R. (1999). Um outro território: Ensaios sobre a mundialização [Another territory: Essays on globalization]. Olho D'água.

Peruzzo, C. M. K. (2005). Mídia regional e local: aspectos conceituais e tendências [Regional and local media: conceptual aspects and trends]. Comunicação \& Sociedade, 26(43), 67-84. https://doi.org/10.15603/21757755/cs.v26n43p67-84

Pesavento, S. J. (2006). Fronteiras culturais em um mundo planetário - paradoxos da(s) identidade(s) sullatino-americana(s) [Cultural borders in a planetary world - paradoxes of South Latin American identity(ies)]. Revista del CESLA, 8(1), 9-19.

Prata, N. (2009). Webradio - novos gêneros, novas formas de interação [Webradio - new genres, new forms of interaction]. Editora Insular.

Prata, N., \& Del Bianco, N. R. (2018). Impacto da migração do radio AM para o FM no Brasil [Impact of migration from AM radio to FM in Brazil]. In Migração do radio AM para o FM - Avaliação de impacto e desafios frente à convergência tecnológica. Editora Insular.

Raddatz, V. L. S. (2011). Rádio AM "avisa": uma expressão da cultura local [AM Radio "warns": an expression of local culture]. In L. Klöckner \& N. Prata (Eds.), Mídia sonora em 4 dimensões: $1^{\text {a }}$ ouvintes e falantes, $2^{\text {a }}$ memória política, $3^{a}$ programas de rádio, $4^{a}$ tecnologia e futuro. EdiPUCRS. 
Ribeiro, A. P. G. (2015). A história oral nos estudos de jornalismo: algumas considerações teóricometodológicas [Oral history in journalism studies: some theoretical-methodological considerations]. Revista Contracampo, 32(2), 73-90. https://doi.org/10.22409/contracampo.v0i32.668

Ronsini, V. M. (2007). Mercadores de sentido: Consumo de mídia em identidades juvenis [Merchants of meaning: Media consumption in youth identities]. Sulina.

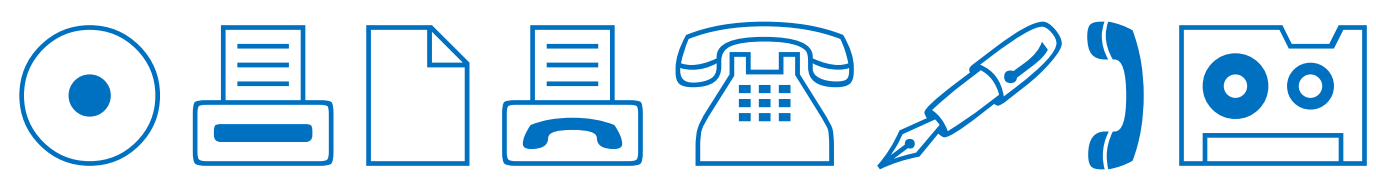

